\title{
STRATEGI PENGEMBANGAN AGRIBISNIS BUAH CIPLUKAN (Physalis peruviana) DI WAAIDA FARM, JAWA BARAT
}

\author{
Muhammad Kemalvin Akbar Nugraha ${ }^{1}$ dan Ernah $^{2}$ \\ ${ }^{1,2}$ Program Studi Agribisnis, Departemen Sosial Ekonomi, Fakultas Pertanian, Universitas \\ Padjadjaran, Sumedang, Indonesia
}

Email: (mkemalvin@gmail.com), (ernah@unpad.ac.id)

\begin{abstract}
Abstrak
Waaida Farm merupakan perusahaan pionir agribisnis ciplukan berjenis Physalis peruviana di Indonesia. Waaida Farm mulai fokus untuk membudidayakan ciplukan karena melihat besarnya peluang pasar ciplukan di Indonesia. Namun sejauh ini Waaida Farm baru mampu memenuhi permintaan dari Pulau Jawa disebabkan oleh produksi yang rendah. Penelitian ini bertujuan untuk memberikan solusi mengenai strategi pengembangan agribisnis ciplukan berdasarkan analisis faktor internal dan eksternal yang dapat dilakukan di Waaida Farm. Penelitian dilakukan dengan desain deskriptif kualitatif dan teknik penelitian studi kasus. Metode pengumpulan data yang digunakan adalah observasi, wawancara dan studi literatur. Dalam menentukan strategi pengembangan yang tepat, diperlukan analisis matriks IFAS, EFAS, IE, SWOT dan QSP. Hasil analisis SWOT menghasilkan lima rumusan strategi yang dapat diterapkan oleh Waaida Farm. Hasil analisis matriks QSP menghasilkan prioritas strategi yang tepat untuk diterapkan oleh Waaida Farm yaitu menginvestasikan profit perusahaan untuk pembelian boks pendingin yang berguna untuk mengatasi kekurangan produksi di periode tertentu dan meningkatkan angka penjualan.
\end{abstract}

Kata kunci: Ciplukan, Strategi Pengembangan Agribisnis, SWOT, QSPM.

\begin{abstract}
Waaida Farm is a pioneer company of agribusiness of Physalis peruviana "ciplukan" in Indonesia. Waaida Farm started its cultivation of "ciplukan" with the considerations of "ciplukan" that has a big market opportunity. However, Waaida Farm could just fulfill the demand from Java so far because of its low production. The object of this research is to give a solution regarding the agribusiness developing strategy of "ciplukan" based on internal and external factors analysis which can be done at Waaida Farm. This research uses descriptivequalitative design and study case research technique. Data collecting method used in this research is through interview and literature study. In needs to find the right developing strategy, there needs to be a matrix analysis of IFAS, EFAS, IE, SWOT and QSP. The SWOT analysis resulted five strategy formulations that can be implemented at Waaida Farm. The matrix QSP analysis resulted the right priority strategy for Waaida Farm, that is to invest the company's profit for purchasing cooler boxes to overcome production shortages in certain periods and to increase the number of sales.
\end{abstract}

Keywords: "Ciplukan", Agribusiness Developing Strategy, SWOT, QSPM.

\section{PENDAHULUAN}

Hortikultura memiliki kontribusi

terhadap PDB yang cenderung

meningkat sebesar $4,67 \%$ dari tahun

2012-2013. Subsektor buah-buahan

merupakan kontributor terbesar diantara subsektor hortikultura lainnya

(Direktorat Jenderal Hortikultura, 2015). Angka tersebut terus meningkat dari tahun 2011-2013. Tingginya nilai PDB subsektor buah-buahan disebabkan oleh tingginya konsumsi produk buah- 
buahan di Indonesia. Konsumsi buahbuahan mengalami peningkatan dari tahun 2011-2013. Pada tahun 2012, masyarakat menghabiskan sekitar Rp 15.443 perbulannya untuk mengonsumsi buah-buahan. Sedangkan pada tahun 2013, angka tersebut mengalami peningkatan menjadi Rp 16.379 perbulan. Angka PDB dan pengeluaran per kapita untuk komoditas buah-buahan di atas menunjukkan bahwa buah-buahan merupakan komoditas hortikultura yang prospektif untuk dikembangkan.

Buah-buahan memiliki peran penting dalam upaya pemenuhan kebutuhan pangan di Indonesia. Ciplukan mengandung nutrisi tinggi dan antioksidan. Buahnya mengandung vitamin A, B, C, B karoten, fosfor dan zat besi. Buah ini juga sumber yang baik untuk provitamin A dan juga mengandung beberapa vitamin B kompleks. Selanjutnya, kandungan lainnya seperti serat $(4,8 \%)$, protein $(0,3 \%)$ dan fosfor $(55 \%)$ juga tidak kalah tinggi. Ekstrak buah menunjukkan aktivitas antioksidan, anti inflamasi dan anti hepatotoksik. Ditambah lagi, buah ini memiliki potensi yang sangat baik sebagai bahan dasar produk anti diabetes dan anti hipertensi. Khasiat lainnya yaitu untuk memelihara kesehatan jantung, memelihara kesehatan ginjal, antioksidan, dan menjaga kadar gula dalam tubuh (Valdenegro, 2013).

Menurut Fischer dan Herrera (2011), ciplukan pada awalnya hanya dikenal sebagai tanaman liar yang tumbuh di lahan kosong. Namun kini, ciplukan telah menjadi buah yang memiliki prospek tinggi bagi pengembang maupun eksportir di berbagai negara. Tabel 1 menunjukkan bahwa Kolombia merupakan negara dengan areal produksi ciplukan terbesar di dunia (800-1000 hektar) dalam satu dekade terakhir dengan hasil panen 15-28 ton per hektar. Pada tahun 2009, Kolombia melakukan ekspor ciplukan ke beberapa negara di Eropa dan Amerika. Harga pasar ekspor ciplukan saat itu mencapai US\$ 3805 per ton.

Tabel 1. Negara Tujuan Kolombia untuk Ekspor Ciplukan Tahun 2009

\begin{tabular}{|l|l|r|}
\hline No. & \multicolumn{1}{|c|}{$\begin{array}{c}\text { Negara } \\
\text { Pengimpor } \\
\text { Ciplukan }\end{array}$} & $\begin{array}{c}\text { Jumlah Impor } \\
\text { (dalam ton) }\end{array}$ \\
\hline 1. & Belanda & 3225,4 \\
2. & Jerman & 1610 \\
3. & Belgia dan & 966.1 \\
& Luksemburg & 214,1 \\
4. & Swedia & 130,4 \\
5. & Prancis & 144,6 \\
6. & Kanada Serikat & 18,4 \\
7. & Amerika Seris & $\mathbf{6 3 0 9}$ \\
\hline \multicolumn{2}{|c|}{ Total } \\
\hline
\end{tabular}

Sumber: Fischer dan Herrera, 2011

Kini, ciplukan dihargai cukup tinggi yaitu Rp 150.000/kg di pasar domestik dan Rp 250.000/kg di pasar mancanegara. Di mancanegara, ciplukan biasanya dikonsumsi dalam bentuk segar maupun olahan seperti salad, pai, kismis dan jeli. Rasanya yang manis dan sedikit masam, bulir yang berair, daging buah yang lembut, serta khasiatnya yang tinggi membuat masyarakat di Amerika Serikat, Jerman dan Singapura sangat menggemari ciplukan (Puente, 2011). Namun di Indonesia, buah ciplukan belum populer 
di kalangan masyarakat karena masih sedikitnya pelaku usaha yang mengkomersilkan buah ciplukan.

Waaida Farm merupakan perusahaan pionir agribisnis ciplukan berjenis Physalis peruviana di Indonesia. Pada awalnya, Waaida Farm merupakan perusahaan yang membudidayakan buah-buahan seperti jambu kristal, talas dan juga perbanyakan bibit tanaman. Namun melihat besarnya peluang pasar ciplukan di Indonesia dengan jumlah produsen yang masih sedikit, ditambah dengan harga jual yang tinggi, Waaida Farm pun mulai fokus untuk

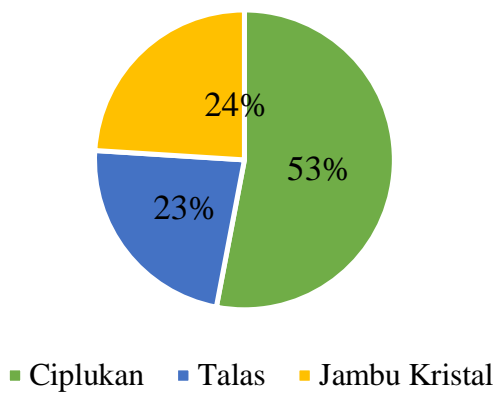

membudidayakan ciplukan sejak tahun 2015.

Gambar 1. Persentase Distribusi Pendapatan Waaida Farm Tahun 2016

Jika diasumsikan bahwa lahan usaha masing-masing komoditas di Waaida Farm adalah satu hektar, maka ciplukan merupakan kontributor pendapatan terbesar di Waaida Farm pada tahun 2016. Gambar 1 menunjukkan bahwa buah ciplukan memiliki kontribusi sebesar 53\% atau Rp 152.693.333 dari pendapatan total Waaida Farm. Jambu kristal selaku komoditas pertama yang dibudidayakan oleh Waaida Farm, mampu menyumbang sekitar $24 \%$ dari pendapatan total atau sekitar $\mathrm{Rp}$
70.440.800. Sedangkan talas

berkontribusi dengan jumlah pendapatan sekitar Rp 66.197.700 atau hanya $23 \%$ dari total pendapatan Waaida Farm. Dengan demikian, ciplukan akan terus dikembangkan melalui strategi-strategi pengembangan untuk dapat memaksimalkan potensi pasar yang tersedia.

Saat ini, target pasar Waaida Farm hanya mencakup Pulau Jawa dengan jumlah pengiriman kurang lebih $200 \mathrm{~kg}$ perbulannya. Padahal, permintaan akan produk ciplukan juga berdatangan dari Pulau Bali dan Kalimantan. Dalam usaha memenuhi permintaan yang datang dari berbagai wilayah tersebut, Waaida Farm mengalami beberapa kendala dalam pengembangan agribisnis ciplukannya. Kendalakendala tersebut diantaranya adalah produktivitas yang kurang optimal, sistem manajemen agribisnis yang kurang baik, minimnya sumber pembiayaan dan sifat buah yang tidak tahan lama.

Hal tersebut menjadi latar belakang peneliti dalam melakukan penelitian yang berjudul "Strategi Pengembangan Agribisnis Buah Ciplukan (Physalis peruviana) di Waaida Farm, Jawa Barat". Hasil analisis strategi pengembangan agribisnis ciplukan Waaida Farm ditujukan untuk memudahkan Waaida Farm dalam mengetahui kekuatan, kelemahan, peluang dan ancaman yang dimiliki dan harus dihadapi sehingga mampu membuat penentuan strategi prioritas yang tepat. 


\section{METODE PENELITIAN}

Objek penelitian adalah strategi pengembangan ciplukan (Physalis peruviana). Sedangkan penelitian dilaksanakan di Waaida Farm, Desa Pamulihan, Kecamatan Pamulihan, Kabupaten Sumedang, Provinsi Jawa. Pemilihan lokasi penelitian didasari oleh Waaida Farm sebagai pionir agribisnis ciplukan di Jawa Barat.

Desain penelitian yang digunakan adalah desain kualitatif. Menurut Sugiyono (2012), desain kualitatif digunakan untuk meneliti kondisi obyek alamiah. Peneliti sendiri berperan sebagai instrumen kunci. Teknik pengumpulan data dilakukan secara triangulasi dan hasil penelitian lebih bersifat makna daripada generalisasi. Sedangkan teknik penelitian yang digunakan adalah studi kasus (case study).

\section{Analisis Matriks IFAS (Internal Factors Analysis Summary)} Menurut David (2009), Matriks IFAS digunakan untuk menganalisis lingkungan internal perusahaan melalui pendekatan fungsional untuk mendapatkan identifikasi kekuatan dan kelemahan di daerah-daerah fungsional perusahaan serta evaluasi hubungan di daerah-daerah tersebut.

\section{Analisis Matriks EFAS (External Factors Analysis Summary)}

Menurut David (2009), Matriks EFAS digunakan untuk menganalisis lingkungan eksternal perusahaan untuk mendapatkan identifikasi peluang dan ancaman bagi perusahaan.

\section{Matriks IE (Internal-External)}

Strategi yang diterapkan perusahaan akan lebih optimal apabila ditentukan berdasarkan kondisi dan posisi perusahaan tersebut. Matriks IE adalah bentuk pemetaan skor total dari Matriks IFAS dan EFAS yang telah dihasilkan (Rangkuti, 2006)

Matriks IE berfungsi untuk mengetahui posisi strategi Waaida Farm. Diagram tersebut dapat mengidentifikasikan sembilan sel strategi perusahaan dalam matriks $I E$, tetapi pada prinsipnya kesembilan sel tersebut dapat dikelompokkan sebagai strategi utama yaitu:

1. Strategi tumbuh dan bina (growth and build) yang berada pada sel I, II, dan IV. Strategi yang tepat untuk diterapkan adalah strategi intensif (penetrasi pasar, pengembangan pasar, dan pengembangan produk/ diversifikasi) atau strategi integratif (integrasi ke depan, ke belakang dan horizontal).

2. Strategi mempertahankan dan memelihara (hold and maintain), yang berada pada sel III, V, atau VII. Strategi penetrasi pasar dan pengembangan produk merupakan dua strategi yang terbanyak dilakukan untuk tipe bagian ini.

3. Strategi panen/divestasi (harvest or divest), yang berada pada sel VI, VIII, dan IX. Strategi yang umum digunakan adalah strategi divestasi dan strategi likuidasi. 


\section{Matriks SWOT}

Dalam memulai sebuah usaha, SWOT merupakan salah satu strategi yang dapat diterapkan yang berfungsi menciptakan rancangan strategi-strategi baru (Rangkuti, 1997). Menurut Hunger dan Wheelen (2012), SWOT merupakan sebuah singkatan yang menggambarkan kekuatan, kelemahan, peluang dan ancaman bagi perusahaan. Sedangkan menurut David (2009), analisis SWOT merupakan sebuah identitas dari faktorfaktor secara sistematis untuk merumuskan strategi pelayanan. Analisis faktor-faktor internal akan menuju kepada identifikasi kekuatan (strength) yang dimiliki dan kelemahan (weakness) yang terdapat di perusahaan tersebut. Sedangkan, analisis faktorfaktor eksternal akan memberikan gambaran mengenai kesempatan (opportunity) yang akan didapat dan ancaman (threat) yang akan dihadapi oleh perusahaan terkait. Matriks SWOT akan memberikan empat sel yang berisi kemungkinan strategi alternatif.

\section{Matriks QSP (Quantitative Strategic Planning)}

Menurut David (2009), Matriks QSP adalah alat yang memungkinkan para penyusun strategi mengevaluasi berbagai strategi alternatif secara objektif, berdasarkan faktor-faktor keberhasilan penting eksternal dan internal yang diidentifikasi sebelumnya. Teknik ini secara objektif menunjukkan strategi mana yang terbaik. QSPM menggunakan analisis input dari Tahap 1 (Matriks IFAS dan Matriks EFAS) dan hasil pencocokan dari analisis Tahap 2 (Matriks SWOT dan Matriks IE).

\section{HASIL DAN PEMBAHASAN}

\section{Analisis Matriks IFAS}

Berdasarkan Analisis Matriks IFAS

(Tabel 2), dapat diketahui bahwa faktor "Sumber Daya Manusia yang Berpengalaman dan Terlatih" merupakan kekuatan utama perusahaan dengan skor 0,436. Sedangkan faktor "Kesulitan Dalam Menerapkan Sistem Rotasi Tanam" merupakan kelemahan utama perusahaan dengan skor 0,1 . Secara keseluruhan, total skor pada Analisis Matriks IFAS ini yaitu sebesar 2,477 . Hal tersebut menunjukkan bahwa Waaida Farm masih belum mampu memanfaatkan kekuatannya dalam menutupi kelemahan secara optimal.

Tabel 2. Analisis Matriks IFAS Buah Ciplukan Waaida Farm

\begin{tabular}{|c|c|c|c|c|}
\hline No. & Faktor Strategi Internal & Bobot & Rating & Skor \\
\hline & \multicolumn{4}{|l|}{ Kekuatan } \\
\hline 1. & $\begin{array}{l}\text { Sumber Daya Manusia yang } \\
\text { Berpengalaman dan Terlatih }\end{array}$ & 0,109 & 4 & $\mathbf{0 , 4 3 6}$ \\
\hline 2. & Modal Internal dan Bebas Hutang & 0,145 & 3 & 0,435 \\
\hline 3. & Tanaman Multi Guna & 0,1 & 3 & 0,3 \\
\hline 4. & $\begin{array}{l}\text { Kualitas Produk Baik yang Berasal dari } \\
\text { Benih Unggulan }\end{array}$ & 0,1 & 3 & 0,3 \\
\hline & \multicolumn{4}{|l|}{ Kelemahan } \\
\hline 1. & Belum Memiliki Boks Pendingin & 0,154 & 2 & 0,308 \\
\hline 2. & $\begin{array}{l}\text { Delegasi Tanggung Jawab Masih } \\
\text { Tumpang Tindih }\end{array}$ & 0,163 & 2 & 0,326 \\
\hline
\end{tabular}




\begin{tabular}{|c|l|c|c|c|}
\hline 3. & Lahan Produksi Terbatas & 0,127 & 1 & 0,127 \\
\hline 4. & $\begin{array}{l}\text { Kesulitan Dalam Menerapkan Sistem } \\
\text { Rotasi Tanam }\end{array}$ & 0,1 & 1 & $\mathbf{0 , 1}$ \\
\hline & \multicolumn{1}{|c|}{ Total } & 1,000 & & $\mathbf{2 , 4 7 7}$ \\
\hline
\end{tabular}

\section{Analisis Matriks EFAS}

Berdasarkan Analisis Matriks EFAS

(Tabel 3), dapat diketahui bahwa faktor

"Online Sales" merupakan faktor yang

mendapat respon paling kuat oleh

Waaida Farm dengan skor 0,464. Hal

ini berbanding lurus dengan penelitian

Mastono $d k k$. (2013), Susanti $d k k$.

(2014) yang menyatakan bahwa untuk

dapat memanfaatkan peluang pasar,

diperlukan strategi-strategi pada aspek

manajemen maupun pemasaran. Dengan

demikian, dapat disimpulkan bahwa

pemasaran merupakan hal yang perlu

dilakukan guna memudahkan perusahaan dalam mengoptimalkan sistem agribisnis dari hulu ke hilir.

Sedangkan faktor "Segmentasi Pasar yang Terbatas" merupakan faktor ancaman utama bagi Waaida Farm dengan skor 0,196. Secara keseluruhan, total skor pada Analisis Matriks EFAS ini yaitu sebesar 2,571. Hal tersebut menunjukkan bahwa Waaida Farm mampu merespon peluang-peluang yang tersedia dan mampu mengatasi ancaman-ancaman yang dapat mengganggu perkembangan usaha Waaida Farm.

Tabel 3. Analisis Matriks EFAS Buah Ciplukan Waaida Farm

\begin{tabular}{|c|l|c|c|c|}
\hline No. & \multicolumn{1}{|c|}{ Faktor Strategi Eksternal } & Bobot & Rating & Skor \\
\hline & Peluang & 0,116 & 4 & $\mathbf{0 , 4 6 4}$ \\
\hline 1. & Online Sales & 0,151 & 3 & 0,453 \\
\hline 2. & $\begin{array}{l}\text { Menjadi Sumber Mata Pencaharian } \\
\text { Masyarakat Sekitar }\end{array}$ & 0,098 & 3 & 0,294 \\
\hline 3. & Perusahaan Sebagai Penentu Harga & 2 & 0,254 \\
\hline 4. & $\begin{array}{l}\text { Reseller Berfungsi Sebagai Mitra untuk } \\
\text { Perluasan Pasar }\end{array}$ & 0,127 & 2 & 0,374 \\
\hline & Ancaman & 0,187 & 2 & 0,348 \\
\hline 1. & Persaingan Pasar yang Tidak Sehat & 0,116 & 3 & 0,375 \\
\hline 2. & Perubahan Cuaca yang Ekstrem & 0,125 & 3 & $\mathbf{0 , 1 9 6}$ \\
\hline 3. & Potensi Persaingan dari Pihak Reseller & 0,098 & 2 & $\mathbf{2 , 5 7 1}$ \\
\hline 4. & Segmentasi Pasar yang Terbatas & 1,000 & & \\
\hline & \multicolumn{2}{|l|}{ Total } & & \\
\hline
\end{tabular}

\section{Analisis Matriks IE}

Kombinasi dari evaluasi Matriks IFAS dan EFAS menghasilkan Matriks IE yang terdiri dari 9 sel. Matriks IE didasarkan atas pada dua dimensi kunci yaitu total skor Matriks IFAS pada sumbu x dengan skor 2,477 dan total skor Matriks EFAS pada sumbu y dengan skor 2,571. Matriks IE (Tabel 4) menempatkan Waaida Farm pada sel V yang menunjukkan strategi "Jaga dan Pertahankan".

Alternatif pilihan strategi yang dapat digunakan adalah strategi intensif, yaitu strategi yang merekomendasikan perusahaan untuk melakukan penetrasi 
pasar, pengembangan produk dan strategi terintegrasi. Strategi penetrasi pasar dapat dilakukan dengan cara promosi dengan lebih gencar lagi supaya memperkuat pasar yang ada saat ini.

Menurut Aghnia (2017), strategi intensif juga meliputi strategi pengembangan produk yang merupakan usaha untuk meningkatkan penjualan dengan cara memodifikasi dan menambah jenis produk dari yang telah ada saat ini. Sebagai contoh, Waaida Farm memiliki opsi untuk mengembangkan lagi produk olahan yang sudah mulai diproduksi seperti kismis dan selai serta memulai untuk mengkomersialisasikan produk olahan lainnya seperti minuman segar. Sedangkan menurut Kamil (2011), strategi terintegrasi perusahaan harus memiliki kendali atas distributor dan petani yang mencakup backward integration, forward integration dan horizontal integration.

Tabel 4. Matriks Internal-Eksternal (IE) Buah Ciplukan Waaida Farm

\section{Skor Total IFAS}

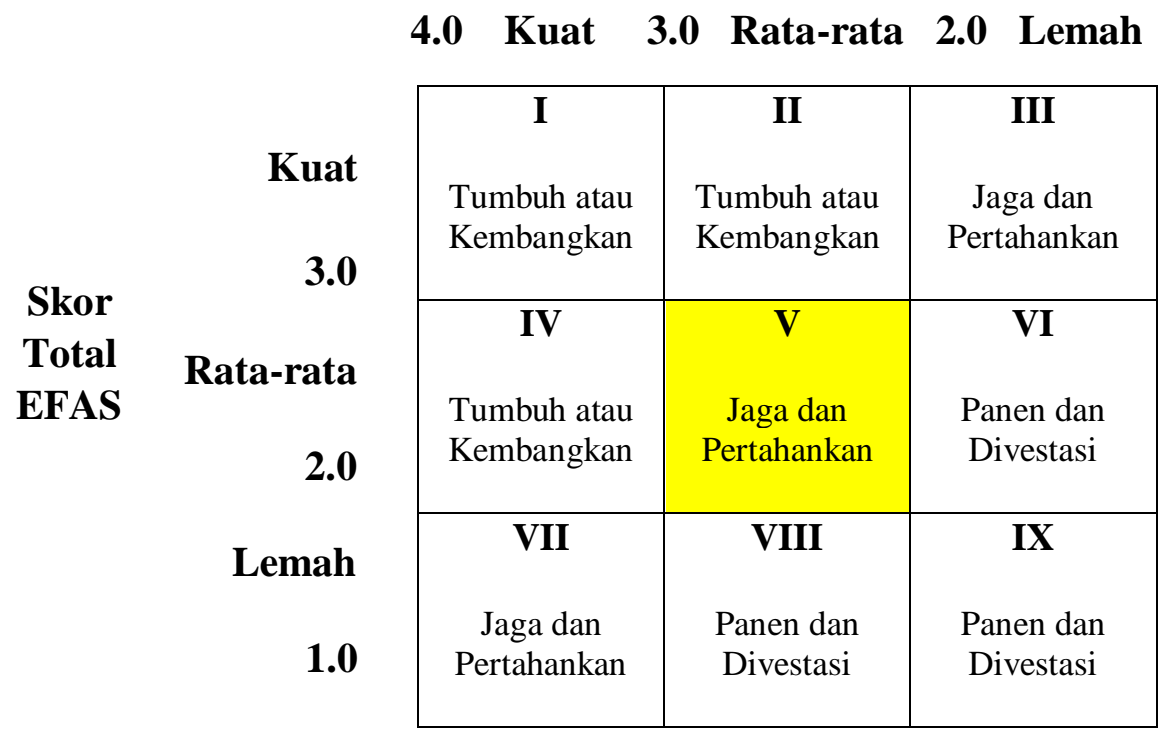

\section{Analisis Matriks SWOT}

Matriks SWOT bertujuan untuk menciptakan berbagai alternatif strategi yang kemudian dapat menjadi referensi bagi perusahaan untuk mengembangkan usahanya. Matriks SWOT (Tabel 5) dirancang berdasarkan analisis kondisi internal dan eksternal perusahaan. 
Tabel 5. Analisis Matriks SWOT Buah Ciplukan Waaida Farm

\begin{tabular}{|c|c|c|}
\hline EKSTERNAL & \begin{tabular}{ll} 
& \multicolumn{2}{c}{ STRENGTH } \\
1. Sumber Daya Manusia \\
yang Berpengalaman dan \\
Terlatih \\
2. Modal Internal dan \\
Bebas Hutang \\
3. Tanaman Multi Guna \\
4. Kualitas Produk Baik \\
yang Berasal dari Benih \\
Unggulan
\end{tabular} & \begin{tabular}{llr} 
& \multicolumn{1}{c}{ WEAKNESS } \\
1. & Belum Memiliki & Boks \\
& Pendingin & \\
2. & Delegasi r & Tanggung \\
& Jawab Masih & Tumpang \\
& Tindih & \\
3. & Lahan & Produksi \\
& Terbatas & \\
4. & Kesulitan & Dalam \\
& Menerapkan & Sistem \\
& Rotasi Tanam & \\
\end{tabular} \\
\hline $\begin{array}{ll}\text { OPPORTUNITY } \\
\text { 1. } \text { Online Sales } \\
\text { 2. Menjadi Sumber Mata } \\
\text { Pencaharian Masyarakat } \\
\text { Sekitar } \\
\text { 3. Perusahaan Sebagai } \\
\text { Penentu Harga } \\
\text { 4. Reseller Berfungsi } \\
\text { Sebagai Mitra untuk } \\
\text { Perluasan Pasar }\end{array}$ & 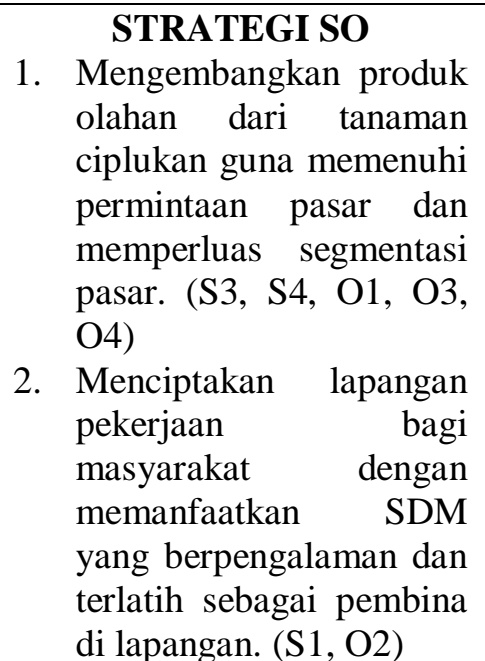 & $\begin{array}{l}\text { STRATEGI WO } \\
\text { 1. Menginvestasikan } \\
\text { profit perusahaan untuk } \\
\text { pembelian boks } \\
\text { pendingin yang } \\
\text { berguna untuk } \\
\text { mengatasi kekurangan } \\
\text { produksi di periode } \\
\text { tertentu dan } \\
\text { meningkatkan angka } \\
\text { penjualan guna } \\
\text { memenuhi permintaan } \\
\text { pasar dan memperkuat } \\
\text { pasar yang ada. (W1, } \\
\text { W3, W4, O1, O3, O4) }\end{array}$ \\
\hline \begin{tabular}{ll}
\multicolumn{1}{c}{ THREAT } \\
1. Persaingan Pasar yang \\
Tidak Sehat \\
2. Perubahan Cuaca yang \\
Ekstrem \\
3. Potensi Persaingan dari \\
Pihak Reseller \\
4. Segmentasi Pasar yang \\
Terbatas
\end{tabular} & $\begin{array}{l}\text { STRATEGI ST } \\
\text { 1. Menjaga kualitas produk } \\
\text { melalui pembelajaran } \\
\text { mengenai teknik } \\
\text { pembibitan yang baik } \\
\text { dan cara untuk } \\
\text { mengantisipasi } \\
\text { perubahan cuaca yang } \\
\text { tidak menentu untuk } \\
\text { menjaga keunggulan } \\
\text { kualitas produk dari para } \\
\text { pesaing. (S1, S4, T1, T2, } \\
\text { T3) }\end{array}$ & $\begin{array}{l}\text { STRATEGI WT } \\
\text { 1. Menginvestasikan } \\
\text { keuntungan perusahaan } \\
\text { untuk memperluas } \\
\text { lahan produksi ciplukan } \\
\text { untuk meningkatkan } \\
\text { angka produksi yang } \\
\text { berguna untuk } \\
\text { memenuhi permintaan } \\
\text { pasar. (W3, W4, T4) }\end{array}$ \\
\hline
\end{tabular}




\section{Analisis Matriks QSP}

Dalam perumusan strategi, tahap terakhir yang harus dilaksanakan adalah menentukan prioritas strategi bagi Waaida Farm menggunakan Matriks QSP. Pilihan-pilihan strategi yang tersedia didapatkan dari Analisis Matriks SWOT yang telah dilakukan sebelumnya. Prioritas strategi dipilih berdasarkan nilai TAS (Daya Tarik Total) tertinggi. Nilai TAS sendiri merupakan hasil perkalian dari skor bobot dengan Nilai AS. Nilai AS merupakan daya tarik masing-masing strategi terhadap faktor-faktor kunci yang dimiliki. Berdasarkan Nilai TAS tertinggi, maka diperoleh prioritas strategi bagi Waaida Farm. Perumusan dan prioritas strategi yang terpilih hanyalah sebagai formulasi strategi yang mana untuk tahap implementasinya merupakan hak dan wewenang Waaida Farm. Tabel 6 menunjukkan hasil analisis Matriks QSP yang telah diurutkan dari yang paling tinggi nilai TAS-nya hingga ke yang paling rendah.

Tabel 6. Analisis Matriks QSPM Buah Ciplukan Waaida Farm

\begin{tabular}{|l|l|c|}
\hline No. & \multicolumn{1}{|c|}{ Alternatif Strategi } & $\begin{array}{c}\text { Total Nilai } \\
\text { Daya Tarik } \\
\text { (TAS) }\end{array}$ \\
\hline 1. & $\begin{array}{l}\text { Menginvestasikan profit perusahaan untuk pembelian boks } \\
\text { pendingin yang berguna untuk mengatasi kekurangan produksi di } \\
\text { periode tertentu dan meningkatkan angka penjualan guna } \\
\text { memenuhi permintaan pasar dan memperkuat pasar yang ada. }\end{array}$ & 7,274 \\
\hline 2. & $\begin{array}{l}\text { Mengembangkan produk olahan dari tanaman ciplukan guna } \\
\text { memenuhi permintaan pasar dan memperluas segmentasi pasar. }\end{array}$ & 7,216 \\
\hline 3. & $\begin{array}{l}\text { Menginvestasikan keuntungan perusahaan untuk memperluas } \\
\text { lahan produksi ciplukan untuk meningkatkan angka produksi } \\
\text { yang berguna untuk memenuhi permintaan pasar. }\end{array}$ & 6,914 \\
\hline 4. & $\begin{array}{l}\text { Menjaga kualitas produk melalui pembelajaran mengenai teknik } \\
\text { pembibitan yang baik dan cara untuk mengantisipasi perubahan } \\
\text { cuaca yang tidak menentu untuk menjaga keunggulan kualitas } \\
\text { produk dari para pesaing. }\end{array}$ & 5,768 \\
\hline 5. & $\begin{array}{l}\text { Menciptakan lapangan pekerjaan bagi masyarakat dengan } \\
\text { memanfaatkan SDM yang berpengalaman dan terlatih sebagai } \\
\text { pembina di lapangan. }\end{array}$ & 4,606 \\
\hline
\end{tabular}

\section{KESIMPULAN}

Analisis Matriks SWOT menghasilkan lima strategi yaitu: (1)

Menginvestasikan profit perusahaan untuk pembelian boks pendingin yang berguna untuk mengatasi kekurangan produksi di periode tertentu dan meningkatkan angka penjualan guna memenuhi permintaan pasar dan memperkuat pasar, (2) Mengembangkan produk olahan dari tanaman ciplukan guna memenuhi permintaan pasar dan memperluas segmentasi pasar, (3) Menginvestasikan keuntungan perusahaan untuk memperluas lahan produksi ciplukan untuk meningkatkan angka produksi yang berguna untuk memenuhi permintaan pasar, (4) Menjaga kualitas produk melalui 
pembelajaran mengenai teknik pembibitan yang baik (5) Menciptakan lapangan pekerjaan bagi masyarakat dengan memanfaatkan SDM yang berpengalaman dan terlatih sebagai pembina di lapangan.

a. Matriks IE merekomendasikan alternatif pilihan strategi yang dapat digunakan yaitu strategi intensif, yang merupakan strategi yang merekomendasikan perusahaan untuk melakukan penetrasi pasar dan pengembangan produk.

b. Strategi prioritas yang paling tepat untuk diterapkan oleh Waaida Farm adalah menginvestasikan profit perusahaan untuk pembelian boks pendingin yang berguna untuk mengatasi kekurangan produksi di periode tertentu dan meningkatkan angka penjualan guna memenuhi permintaan pasar dan memperkuat pasar yang ada.

\section{DAFTAR PUSTAKA}

Aghnia, Fitri. 2017. Strategi Bersaing Agroindustri Teh Rakyat. Skripsi. Fakultas Pertanian. Universitas Padjajaran.

David, Fred. R. 2009. Manajemen Strategis Konsep Edisi 12. Salemba Empat., Jakarta

Direktorat Jenderal Hortikultura Kementerian Pertanian. 2015. Rencana Strategis Direktorat Jenderal Pertanian Tahun 20152019. pertanian.go.id. Diakses 13 Juli 2017.
Fischer, G dan Herrera, A. 2011. Cape

Gooseberry (Physalis

peruviana). pp. 374-397.

Woodhead Publishing Limited, Colombia

Hunger, David dan Thomas Wheelen. 2003. Manajemen Strategis. Penerbit Andi, Yogyakarta

Kamil, Firman. 2011. Strategi Pengembangan Usaha Sayuran Organik di Permata Hati Organic Farm Kabupaten Bogor, Jawa Barat. Skripsi. Fakultas Ekonomi dan Manajemen. Institut Pertanian Bogor. <repository.ipb.ac.id> diakses pada 11 Juli 2017 pukul 11.22.

Mastono $d k k$. 2013. Peluang Usaha Atap Daun Nipah Bagi Masyarakat di Kelurahan Timbau Tenggarong Kabupaten Kutai Kartanegara Provinsi Kalimantan Timur. XII (1).

Puente, Luis A. 2011. Physalis peruviana, The Multiple Properties of a Highly Functional Fruit. Food Research International, Colombia

Rangkuti, Freddy. 2017. Analisis SWOT: Teknik Membedah Kasus Bisnis. Gramedia, Jakarta 1997. Analisis

SWOT: Teknik Membedah Kasus Bisnis. Gramedia, Jakarta

Sugiyono. 2012. Metode Penelitian Kuantitatif, Kualitatif dan R\&D. Alfabeta., Bandung

Susanti, Tuti $d k k$. 2014. Analisis Pendapatan dan Pemasaran 
Usahatani Pepaya Mini (Carica papaya L.) di Kelurahan Teritip Kecamatan Balikpapan Timur Kota Balikpapan. XIII (1).

Valdenegro et al. 2013. The Effects of Drying Proccesses On
Organoleptic Characteristics and The Health Quality of Food Ingredients Obtained From Golden Berry Fruits (Physalis peruviana). II (2). 1 